\title{
A Study on the Plight of Women in the Screen Industry
}

\author{
Xuan Luo ${ }^{1 *}$, Yiting Huang ${ }^{2}$
}

\author{
${ }^{1}$ the University of Melbourne \\ ${ }^{2}$ Communication University of China, Nanjing \\ *Corresponding author.Email:xualuo77@163.com
}

\begin{abstract}
This article focuses on the issue of gender, which has already become the inevitable trend in the Chinese screen industry as a whole. With the rapid development of the screen industry currently, more and more people pay attention to singers, actors, and there are people who do research about the contemporary screen industry, in particular film industry, but few researchers have acquired the knowledge behind the stage - the screen workers' current situation. What is the gender distribution in the movie and television industry? What does this distribution represent? What are the reasons for the gender imbalance in the industry? There are several examples and industry data to analysis the problems, but more importantly, this paper pays more attention to how people handled the imbalanced phenomenon.

This work will try to solve the above problems, and it illustrates that the public can establish some funds to support females in artwork and the official could organize some activities to rise female awareness. Moreover, it offers an exciting opportunity to advance people's knowledge about sexism in the screen industry, which may provide a better working environment for workers in the screen industry.
\end{abstract}

Keywords: Chinese screen industry, gender issue, women, gender dilemma, screen workers.

\section{INTRODUCTION}

"Screen" means the screening platform that narrates the artistic content 0 , and "screen production" is the process of creating and expressing those stories 0 . Simply speaking, the screen industry is a maledominated career 0 , there are numerous reasons why the workplace has gender inequalities, Some people argue the screen industry is a physical occupation, it is better to do by men, some people figures that women are often sacrificing their careers because of their families. However, with the awakening of female consciousness, the issue of gender problems has received considerable critical attention, furthermore, A number of researchers have researched the gender imbalance phenomenon, because if this phenomenon becomes worse, the female will lose social discourse power gradually.

This paper seeks to remedy these problems by document analysis, it has been divided into three parts. First of all, this article provides data from primary and secondary sources and illustrates the gender issues that screen workers are suffering from. Second, this paper will introduce several illustrations to demonstrate, find root causes, and points out the consequence of these problems. Finally, this article suggests that building the public fund institution and organizing some female topic activities are reliable methods to help female film workers and promote their careers.

\section{METHODOLOGY}

In order to explore the female element in the screen industry, this paper decided to analyze the gender ratio of directors of domestic films released in Chinese cinemas between 2017 - 2020. Because this content must be reliable, thus this work collected information on the official website. In addition, the work had collected other two types of data from the perspective of social reality, from archival documents, and secondary sources. In the data collection process, the paper analyzed and summarized the texts to be considered. Furthermore, simple descriptive statistics and comparative analyses were carried out in this paper as an aid to the research.

Documents analysis was also used in this paper and researched documents from China to Australia. We expanded the scope of document searches to confirm that gender inequality in the screen industry not only exists in China but also in the global screen industry. This also provides a more in-depth understanding of female awareness and emotions. Overall, applying these methods, we have several valuable features, first, we 
can understand and judge the key issues of women in the screen industry in recent years and can visualize them. Second, when we examine documents, we can also observe and explore official attitudes and popular opinions.

\section{GENDER ISSUES IN SCREEN INDUSTRY}

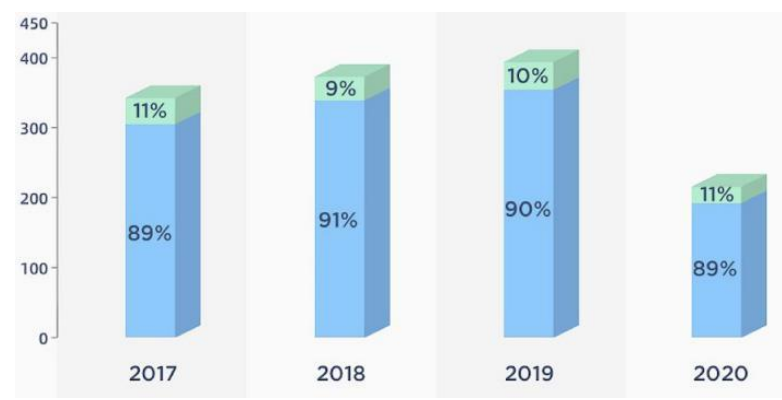

Figure 1 Gender ratio of directors of domestic films released in domestic cinemas

(Blue: Male; Green: Female )

The roles of genders could be regarded as cultural expectations, which determine the different behaviors of men and women in their daily lives 0 . There is no doubt that women in their daily duties of family life, such as pregnancy, childbirth, child education, family labor, are the barriers to entry for their career, and the above situations also happen in the screen industry.

In figure 1, the ONE International Women's Film Festival shows that the proportion of men and women in the screen industry has been relatively stable in recent years0. According to the data from the China Film organization 0 , from 2017 to 2020 , a total of 1,499 domestic films were released in domestic theaters, the number of male directors is ten times of female directors Although the number of works produced by female directors in 2019 only accounted for $10 \%$ of the total, which is the most in the past four years, the origin cause is that the overall number of films produced in 2019 is the highest. Compared with 2019, with the widespread and dramatic increase of COVID-19 cases in Chinese, the overall number of Chinese film production in 2020 has sharply decreased by about half, however, there is no obvious change in terms of gender ratio. What's worse, the ONE International Women's Film Festival pointed out that among the 1,499 films, films focusing on women's issues are even rarer, accounting for only $23.65 \%$ of them.

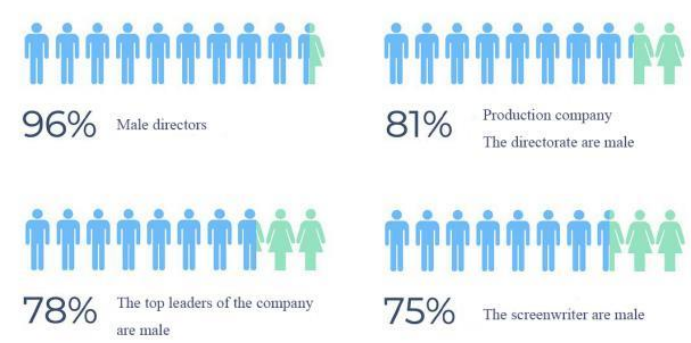

Figure 2 Proportion of men and women in other positions in the screen industry

(Blue: Male; Green: Female )

As figure 2 above indicates, no matter it is in the company or in the different responsibilities of filmmaking, it is noteworthy that all 4 types of jobs are made up mostly by men, in other words, the number of males is far higher than females. Combined data for each set, reveals the following:

In terms of the leader in the company, there is nearly 80 percent of team leaders are male. In the director, the proportion of women is extremely low, only 4 percent, whereas the number of women in the scriptwriter is relatively high, with about 15 percent of screenwriters being women. Thus, broadly speaking, the male has an absolute say in the screen industry. However, this problem appears not only in China but also all over the world. According to the information from Screen Australia, the number of women guiding feature films in Australia over the last five years has been no more than $20 \%$. In addition, concerning the access to investment, whether government or private funding, it seems that male producers gain access to the funding more easily than female producers 0. Moreover, the Australian Human Rights Commission points out that, one in fifth women and one in twentieth men report sexual harassment in the workplace 0 , therefore, it is obviously found that among employees, the proportion of women who are harassed is much higher than that of men. According to the Asociación de Mujeres Cineastas y de los Medios Audiovisuales in 2017 0, the proportion of men in the Spanish film industry is $76 \%$, and that of women is only 24\%. Although there is still gender imbalance, the overall proportion is slightly less than that in China. In Korea, LE 0 finger that gender inequality brings some huge challenges for South Korean women because many talented women are denied the opportunity to show themselves. At the same time, Kim Sunah who is a director of Seoul International Women's Film Festival demonstrated that as a matter of fact in film colleges, the proportion of men and women is very equal, about is 50:50, however, the production rate of short films is $30: 70$ and only $12 \%$ feature films are made by women, mostly independent productions, what worse, less than 10 percent of female 
directors make commercial films 0 , this situation is really same as China .

Discover with excitement, there are more and more female film works appearing in the industry. It is true that in terms of thinking, women's films are completely different from men's films, but which will bring more new ideas to the film industry. For example, the female film "My sister" 0 is very popular in early 2021. Compared with the film "Take my brother away"0, although both films are about the feelings between brothers and sisters, the difference is that "my sister" uses a female perspective to show the personal dream and practical difficulties in people's life. The sister is the leading role of the film, she is not attached to any male role to develop the story, which highlights the characteristics of women's independence in the new era. Furthermore, the works of female directors have richer emotional plots, more delicate shooting techniques, and emotional treatment, besides, each role is very threedimensional. The film uses much large depth of field lenses to express the character's state. From the supporting roles, aunt, brother, and uncle, although uncle is unctuous, it is easy to notice that he wants to make every effort to compensate his daughter in life. The aunt doesn't agree with the heroine to send her brother away, but it is a paradox that she doesn't want heroine to go her own way again.

It can be seen that women have gradually joined the male-dominated screen industry and tell stories from diverse perspectives. Although the logic of My sister is slightly immature compared with more mature maledominated films, it can at least bring a new experience to the audience. If My sister avoids procrastination in handle with feelings, If the director adds deeper thinking on gender issues, the film will bring more social discussion, not just "Empathy".

\section{WHY THE GENDER PROBLEM APPEARS IN THE SCREEN INDUSTRY}

There are several reasons for the gender problem in the screen industry. First of all, in China there are some traditional cultures between different gender. What is the traditional gender culture in China? Lingge points out that the traditional Chinese gender culture is a male monoculture and originates from the patriarchal society with men as the main body. From the feudal society in ancient China, the female is supposed to obey "the three obediences and four virtues", and so on. The male is the successor of the family and has relatively stable family status and social relations, while the female is subordinate and is excluded from the main culture. Men should be indomitable and uphold the family, while women should be docile, a good wife and mother, as a good "wife", until now, people always say a slang:" men's work centers around outside, women's work centers around the home". In addition, there is fixed thinking that men are synonymous with breadwinners 0 , these traditional gender biases suggest that men perform better than women at work, and they believe that men are more valuable than women, especially in screen industries, which usually require more physical strength. The second reason is the lack of self-confidence. Screen Australia 0 in women in the Australian Screen Industry indicates that "women are far more likely than their male counterparts to underestimate and undersell their skills and abilities, whose effect is that women have to be perceived as lacking confidence, and are less likely to push themselves forward." Compared with male power, women's strength is relatively weak. When feeling the disparity of power from the outside, people are intended to retreat because of fear, that is, there is no sufficient self-confidence. But, in fact, each possesses his own advantages. Indeed, the male leaders, whose expectations of completing the task are very straightforward, pay more attention to the mission, and female leaders emphasize democracy and team spirit. On the contrary, if the screen industry has been imbalance on gender issues for a long time, it is difficult to develop cultural diversity, which means that the industry has not injected new ideas, results in slow or single development of the industry, directly lead to the ratings of programs or movies (reading volume) decrease sharply, therefore affecting the whole industry's income.

\section{HOW TO DEAL WITH THE SITUATION}

With a view to undertaking this issue, establishing a public fund institution is a reliable method to help female film workers promote their careers. For example, the South Korean government organized the Women's Fund, which is exceptional energy to stimulate awareness and improve industrial activity for women. The fund will be comprehensive and without any work limitations, from the film genre to stage. Besides, Seoul International Women's Film Festival 2020 developed a new part called 'Linkage: Director $\times$ Critic'. They invited seven Korean women filmmakers 0, who have produced films in 2019 or 2020 . 'Linkage: Director $\times$ Critic' invite people to watch their films and have some discussions, in order to reinforce the female's discourse of films, grow the public's "female consciousness", improve female film worker's fame, and provide talented women with opportunities to express themselves.

In China, at the end of 2019, a report on the "gender ratio inventory of China's 31 provinces" in China Statistical Yearbook wrote that Sichuan has become the only region in China with more women and fewer men 0 . Southwest of China has a rich foundation of national culture and film, at the same time, Sichuan province is actively promoting the upgrading and construction of the film and television industry, for example, the ONE 
International Women's Film Festival is held here, in addition, during the international women's day, the project of "women's classic film screening month" was launched in the screening Hall of Chengdu Heping cinema. At the launching ceremony, nearly 100 women representatives from all communities in Chengdu could come to watch films for free.

\section{CONCLUSION}

The study has gone some way towards enhancing our understanding of gender imbalance in the screen industry, and it demonstrates that in China, since some traditional thinking and their lack of self-confidence attitudes, they do not have a seat in the screen industry. After researching documents from Korea and Australia, we can understand the gender issue in the screen industry already happens all around the world. This paper suggests that establishing some female topic public activities and organizing funds for female screen workers will also help them to display them in the industry.

The study is limited by the lack of information on real experiences, thus, it would be interesting to take some interviews and compare experiences of different gender within the screen industry. It is recommended that further research be undertaken, for example, keep the investigation on female funds development, find some interviewer to collect their experiences and explore more policy on a female would help us to establish a greater degree of accuracy on this matter.

\section{AUTHORS' CONTRIBUTIONS}

Xuan Luo carried out the studies, performed the analysis, drafted the manuscript, and finished the paper.

YiTing Huang collected the data from official websites and documents, analyzed the data and delivered to Xuan Luo.

\section{REFERENCES}

[1] Queensland Department of Premier and Cabinet, Advance Queensland 10-Year Roadmap for the Scr een Industry Consultation Paper, 2017.

[2] Screen production in Australia: Independent screen production, Industry census, Screen Producers Aust ralia, 2018.

[3] A. Cameron, D. Verhoeven, \& D. Court, Above the Bottom Line: Understanding Australian Screen Co ntent Producers, Media International Australia, Inc orporating Culture and Policy, vol. 90, 2010, pp. 13 6.

[4] Z. James, Sociology, McGraw-Hill, 1990.
[5] the ONE International Women's Film Festival sho ws, Retrieved from http://www.oneiwff.com, 2021.

[6] China Film organization, Retrieved from http://ww w.chinafilm.org.cn, 2021.

[7] Screen Australia, Women in the Australian Screen Industry, Retrieved from https://www.screenaustral ia.gov.au/getmedia/f20beab8-81cc-4499-92e9-02af ba18c438/Gender-Matters-Women-in-the-Australia n-Screen-Industry.pdf, 2015.

[8] R. Siemienowicz, ZERO TOLERANCE FOR SCR EEN-INDUSTRY SEXUAL HARASSMENT. Met ro : Media \& Education Magazine, 2018, pp. 116.

[9] “Asociación de Mujeres Cineastas y de los Medios Audiovisuales.” Accessed October 11, https://cima mujerescineastas.es/. 2021.

[10] L. EVE, "Women Leaders in South Korea: Challen ges and Opportunities." eveprogramme, 2018, JUL Y 6, https://www.eveprogramme.com/en/36448/wo men-leaders-in-south-korea-challenges-and-opport unities/.

[11] J. Noh, "Film industry gender equality centre launc hes in Korea." Screendaily, https://www.screendail y.com/news/film-industry-gender-equality-centre-1 aunches-in-korea/5127402.article, March 13, 2018.

[12] Y. Ruoxin, My sister, 2021.

[13] D. fenfen, Take my brother away, 2021.

[14] D. Jones, \& J. K. Pringle, Unmanageable inequaliti es: sexism in the film industry, Sociological Revie w Monograph, vol. 63(S1), 2015, pp. 37-49.

[15] “22ND SIWFF”, SEOUL INTERNATIONAL WO MEN'S FILM FESTIVAL, Accessed http://siwff.o r.kr/eng/, 2020.

[16] National Bureu of Statistics of China, CHINA STA TISTICAL YEARBOOK, Retrieved from http://w ww.stats.gov.cn/tjsj/ndsj/2020/indexch.ht, 2020. 